\title{
BIOSTRATIGRAPHY OF EARLY EOCENE MARGALA HILL LIMESTONE IN THE MUZAFFARABAD AREA (KASHMIR BASIN, AZAD JAMMU AND KASHMIR)
}

Amir shahzad ${ }^{* 3}$, Munir ul hassan munir ${ }^{1}$, Muhammad Yasin' $^{1}$, Muhammad Umar $^{2}$, Syed Rameez, Rafique Samad $^{3}$, SibtanAltaf $^{3}$, Yasir Sarfraz ${ }^{1}$

${ }^{1}$ Institute of Geoloy, University of Azad Jammu and Kashmir, Muzaffarabad, Pakistan

${ }^{2}$ Department of Earth science, Comsats, Abbottabad, Pakistan.

${ }^{3}$ Department of Geology, University of Azad Jammu and Kashmir, Neelum Campus, Pakistan *Corresponding author email: amirshahzadgeo@gmail.com

This is an open access article distributed under the Creative Commons Attribution License, which permits unrestricted use, distribution, and reproduction in any medium, provided the original work is properly cited

\section{ARTICLE DETAILS}

\section{Article history:}

Received 12 May 2017

Accepted 12 July 2017

Available online 17 October 2017

\section{Keywords:}

Margalla Hill Limestone, Battlian, Forams, Nummulites, Lockhartia

\section{ABSTRACT}

The Early Eocene Margalla Hill Limestone is well exposed in core of Hazara Kashmir Syntaxis. A section at Battlian is measured and sampled for paleontological studies, where its lower contact with Patala Formation and upper contact with Chorgali Formation is transitional and conformable. The total observed thickness is 73 meters and 60 samples were collected from bottom to top at different levels, 50 thin sections were studied. 19 species of larger forams including age diagnostic Nummulites mamillatus, Nummulites atacicus, Assilina spinosa, Assilina laminosa, Assilina granulosa, Assilina exponens, Textularia sp., Miliolid sp., Alveoloina pasticillata, Alveolina elliptica, Alveolina ovulum, Quinqueloculina, Discocyclina peruviana, Rotalia trochidiformis, Ranikothalia sindensis, Skeasaria ornata Nodosaria sp., Lockhartia tipper and Dasycladacean algae were also observed. In conclusions, presence of benthic foraminifera indicated that Margala Hill Limestone was deposited in Neotethys warm and shallow marine in the Battlian area Muzaffarabad, whereas early Eocene age is assigned on the basis of benthic foraminifera observed.

\section{INTRODUCTION}

Geologicaly Battlian area lies in the core of Hazara Kashmir Syntaxis (Figure 1) which is situated in the Kashmir Basin. The formations exposed in the area are entirely sedimentary in nature. These include Abbottabad Formation, Hangu Formation, Lockhart Limestone, Patala Formation, Margala Hill Limestone, Chorgali Formation, Kuldana Formation, Murree Formation and Recent Alluvium (Table 1). This area belongs to eastern Tethyian and was classic for the tropical to sub-tropical marine sedimentary deposition. Special emphasis is given for the micropaleontological studies of the Lower Eocene Margala Hill Limestone. The Margala Hill Limestone dominantly consists of Limestone with subordinate shales and marls, limestone is highly fossiliferous and the size of fossils ranges from $8 \mathrm{~mm}$ in length and $3.5 \mathrm{~mm}$ in width which is also measured in the field. The total observed thickness of Margala Hill Limestone is 73 meters (Figure 2) The foraminifra have an important role in biostratigraphic studies. Foraminifera are marine and single celled eukaryotes. Diversity of species generally show shallow marine environment with low or high energy and favorable salinity condition. Maximum fossils assemblage increases offshore in photic or neretic zone along inner shelf and decreases in deep water and low temperature (Plate 1-5). The foraminiferal species belong to genera Nummulites, Lockhartia Assilina, Alveolina Ranikothalia Textularia Nodosaria Discocyclina, Rotalia and Quinqueoculina was studied. Presence of these benthic foraminifera indicated that Margala Hill Limestone were deposited in the tidal flat environments (i.e., ranging from supratidal to subtidal conditions).

Table 1: Stratigraphic succession of Battlian area, Muzaffarabad, Azad Kashmir, Pakistan.

\begin{tabular}{|c|c|}
\hline Age & Formation \\
\hline Recent & Alluvium \\
\hline \multicolumn{2}{|c|}{ 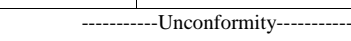 } \\
\hline Miocene & Murree Formation \\
\hline \multicolumn{2}{|c|}{ - } \\
\hline Middle Eocene & Kuldana Formation \\
\hline Early Eocene & Chor Gali Formation \\
\hline Early Eocene & Margala Hill Limestone \\
\hline Late Paleocene & Patala Formation \\
\hline Late Paleocene & Lockhart Limestone \\
\hline $\begin{array}{l}\text { Early } \\
\text { Paleocene }\end{array}$ & Hangu Formation \\
\hline \multicolumn{2}{|c|}{----------Unconformity---------- } \\
\hline Cambrian & Abbottabad Formation \\
\hline
\end{tabular}

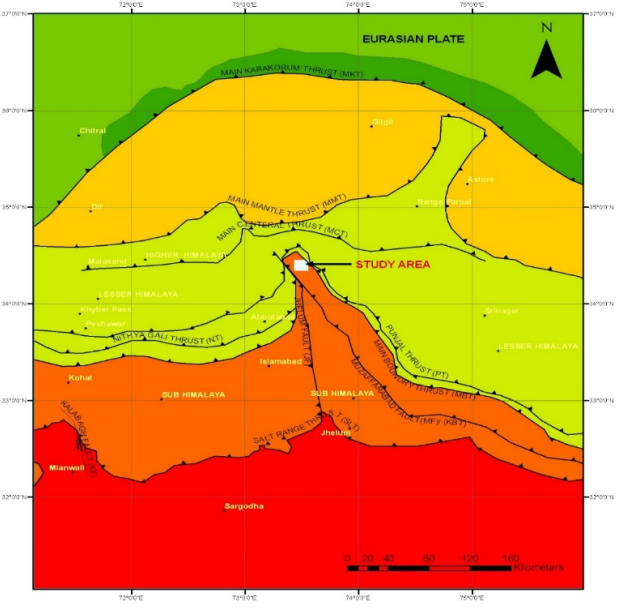

Figure 1: Tectonic map of Himalayas. Rectangle shows study area.

\section{PREVIOUS WORK}

The study area has remained a site of deep interest for the geologists working on stratigraphy and tectonics. The geology and stratigraphy of this region was originally introduced by a group researcher and as "Nummulitic Limestone" to the Paleogene strata [1]. A scientist also has described various stratigraphic units and his work was of regional nature [2]. On other research, a group researcher also has discussed the geology of the area [3]. There also some scientist described the stratigraphy of Kotli area of Azad Kashmir and its correlation with different areas of Pakistan. Besides, a researcher described the lithological, stratigraphic and structural features of Hazara-Kashmir Syntaxis [4]. The Late Cenozoic tectonics and sedimentation in the north-west Himalayan foredeep [5]. Some researcher has worked on the orogenesis of the area [6]. Well and Gingreich described paleoenvironmental interpretation of Paleogene strata near Kotli, in collaboration with Institute of Geology Azad Jammu and Kashmir University described the lithological, stratigraphic and structural features of Hazara Kashmir Syntaxis [7,8]. The Swiss Geologist described the stratigraphic and metamorphic features of the rocks of the Hazara-Kashmir Syntaxis [9]. A researcher has described the ecology and micropaleontology 
of Paleocene-Eocene carbonates of Hazara- Kashmir Basin. A group researcher discussed the active fault of the Hazara Kashmir Syntaxis regarding to their geomorphic expression, Quaternary displacement and seismic potential and geological point of view [10].

The active faulting and earthquake deformation in Hazara-Kashmir Syntaxis,Azad Kashmir [11]. The biostratigraphy of Muzaffrarabad and Kotli area. Sedimentology and micropaleontology of Paleocene-Eocene carbonates of Potwar and Hazara areas are extensively studied by various authors $[12,13]$. However, this area is not extensively investigated.

\section{METHODOLOGY}

Thickness of the selected section was measured for the preparation of stratigraphic column and the detail of lithology was also written along with the stratigraphic column. Rocks samples were collected from the bottom to top at unequal distance. The distance between two samples was managed in such way that at least one sample was collected from each bed. Hard samples were taken from fresh outcrop with the help of geological hammer. Loose samples were also collected for the extraction of microfossils and thin section were prepared from hard samples for micropaleontological studies. The larger foraminifera up to specific level investigated from thinsection. Trinoculur stero zoom microscope was used for identifaction and ptotography of formaninfra.

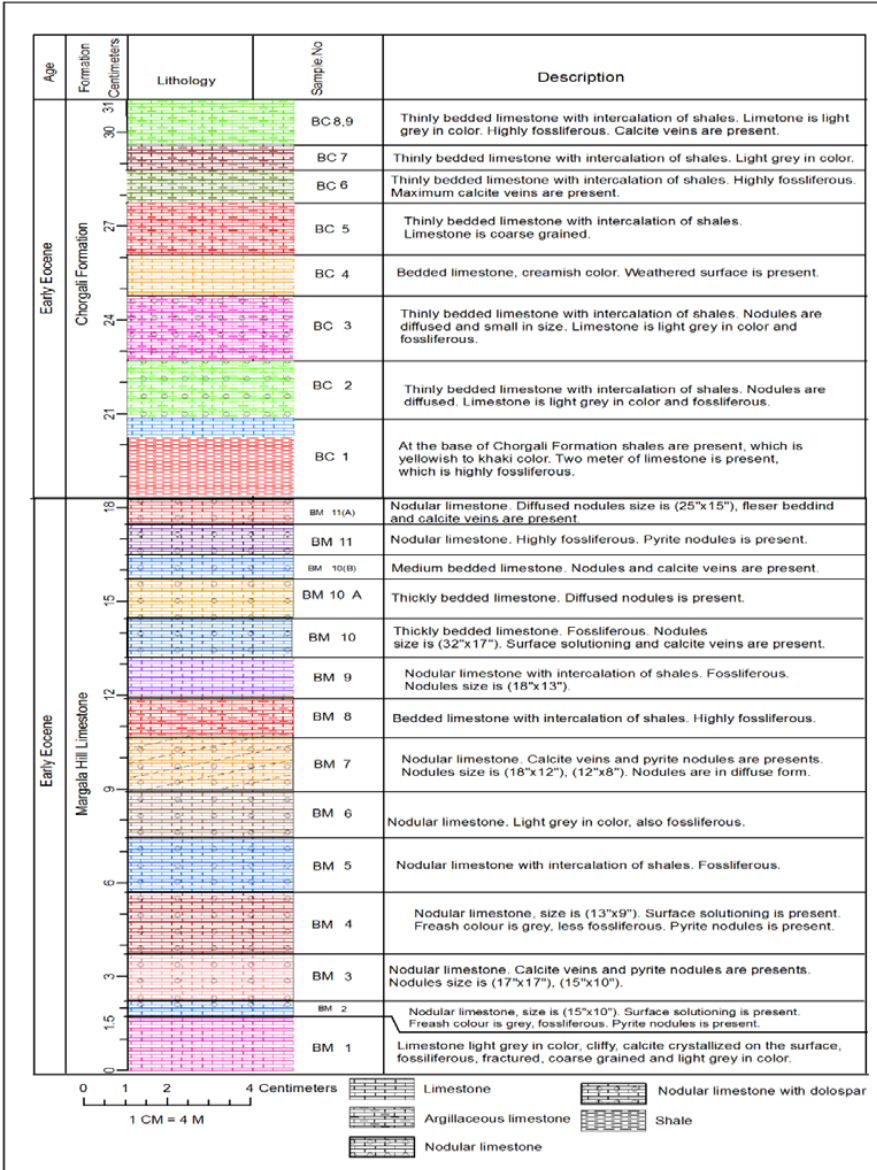

Figure 2: litholog of Margala Hill Limetone.

\subsection{Biostratigraphy of the Early Eocene sequence}

The Battlian area is geologically investigated for benthic larger and smaller foraminifers (Plates 1-3). For this purpose, 60 rock samples are collected from. Margala Hill Limestone. Iprepared thin section slides for the micropaleontological studies. The foraminiferal species are good index fossils for age determination of the rock units because these are restricted in stratigraphic ranges. These species are quite common in the equivalent geological deposits of northern Pakistan and other parts of the world. This is the good criteria for the regional and inter-regional correlation of the strata using the age diagnostic species of foraminifers. The detailed biostratigraphy of Margala Hill Limestone of Battlian area is presented as follows:

\subsubsection{Margala Hill Limestone}

In the study area Margala Hill Limestone consists of limestone, marls and shales. Limestone is highly fossiliferousand the size of fossils ranges from $8 \mathrm{~mm}$ in length and $3.5 \mathrm{~mm}$ in width which isalso measured in the field. In Battlian section limestone is nodular and medium bedded (Photos 1 and 2.2)

and average nodule size is 15 inches in length and 10 inches in width. Pyrite nodules have also noticed. Shale sare also present along with marls and the color of shale is light greenish to dark gray. The size of nodules ranges from 19 to 58 inches in length and 14 to 25 inches in width. Calcite veins and diffused nodulesare also present at some places. Nodules are surrounded by clayey material. Towards top nodules size, fossils content, solutioning and flaser bedding are dominant. By the detail petrographic studies following foraminifra were identified which includes Nummulites atacicus (LEYMERIE), Nummulites mamillatus (FICHTEL and MOLL), Assilina spinosa (DAVIES and PINFOLD,), Assilina laminose (GILL) Assilina exponens (SOWERBY), Textularia sp., (DEFRANCE), Alveolina Vredenburgi (DAVIES), Miliolid sp., (d' ORBIGNY) Ranikothalia sendensis (DAVIES) Discocyclina peruviana (CUSHMAN), Rotalia trochidiformis (LAMARCK), Alveoloina pasticillata (SCHWAGER), Alveolina elliptica (SOWERBY), Quinqueloculina (d' ORBIGNY) Miliolid sp., (d' ORBIGNY) Alveolina ovulum (SOWERBY) Nodosaria sp (LEMARCK) Lockhartia tipper (DAVIES), Dasycladacean algae (Plate1-3). and shells of mollusks hasbeen observed in outcrop. The thickness of this formation is 73 meters in Battlian area on the basis of above mention foraminifra the Early Eocene age is assign for Margalla Hill Limestone.

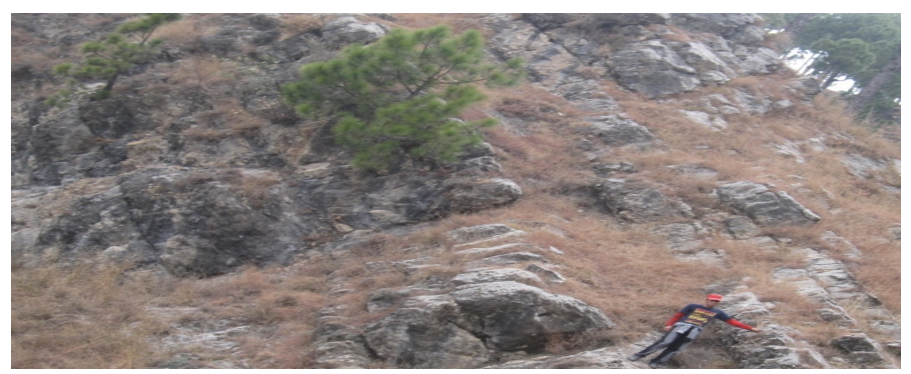

Photo 1: An outcrop of MargalaHill Limestone in Battlian section.

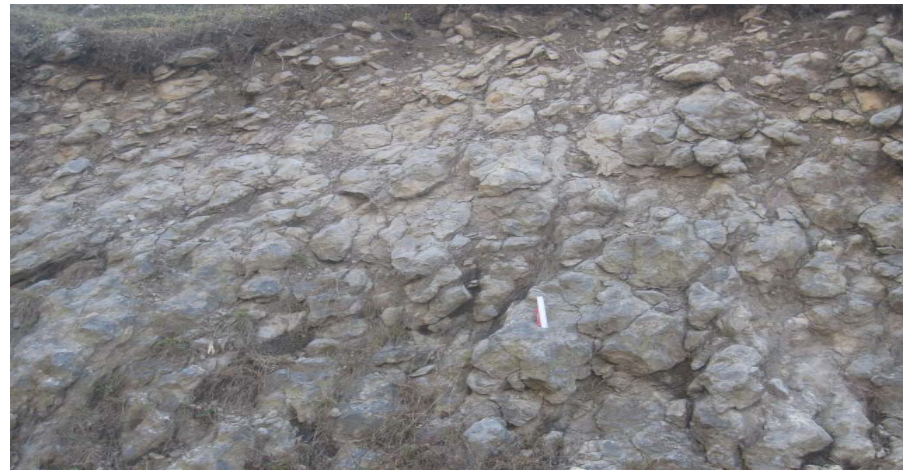

Photo 2: The outcrop of Margala Hill Limestone showing well develop nodularity near Battlian section.

Plate 1

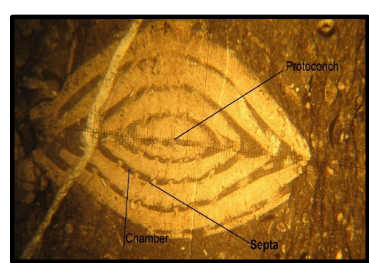

Figure 1: Meridian section of Nummilites atacicus

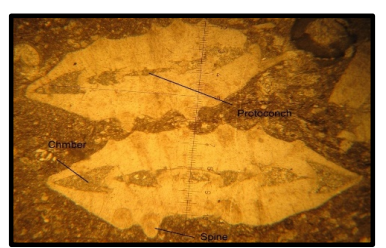

Figure 3: Meridian section of Assilina spinosa

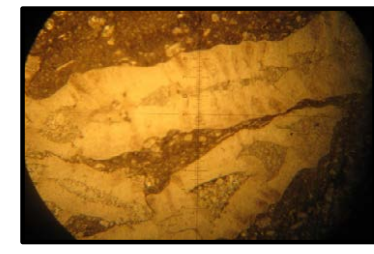

Figure 5: Meridian section of Assilina exponens

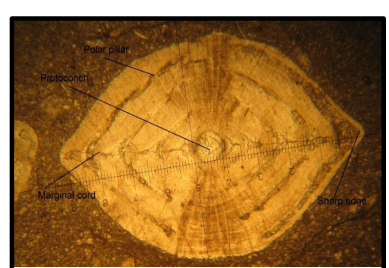

Figure 2: Meridian section of Nummulites mamillatus

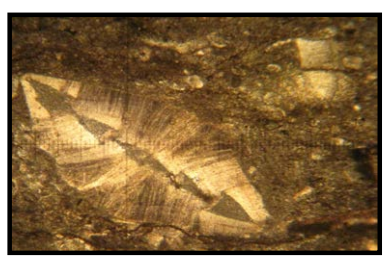

Figure 4: Meridian section of Assilina laminosa

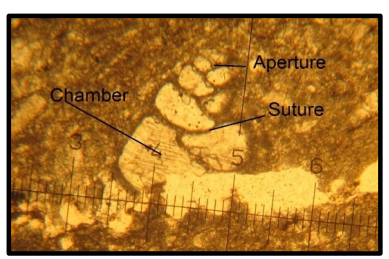

Figure 6: Axial section of Textularia sp.

Cite this article as: Amir shahzad, Munir ul hassan munir, Muhammad Yasin, Muhammad Umar, Syed Rameez, Rafique Samad, Sibtan Altaf, Yasir Sarfraz

(2017). Biostratigraphy Of Early Eocene Margala Hill Limestone In The Muzaffarabad Area (Kashmir Basin, Azad Jammu And Kashmir). Pakistan Journal of Geology, 1(2):16-20. 
Plate 2

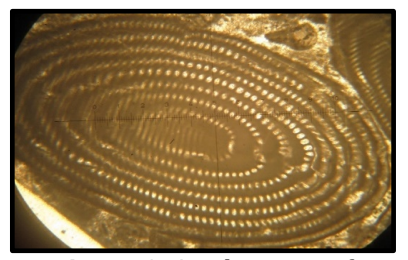

Figure 1: Axial section of Alveolina verdenburgi

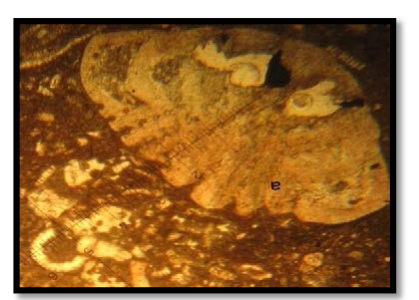

Figure 3: Meridian section of Lockhartia tipperi

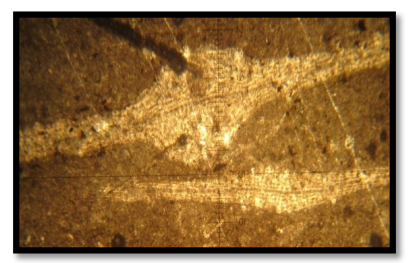

Figure 5: Discocyclina peruviana

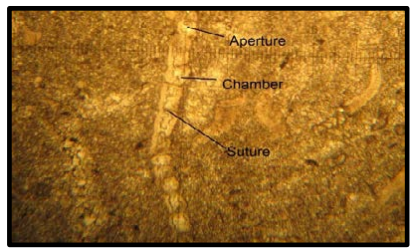

Figure 2: Axial section of

Nodosaria sp.,

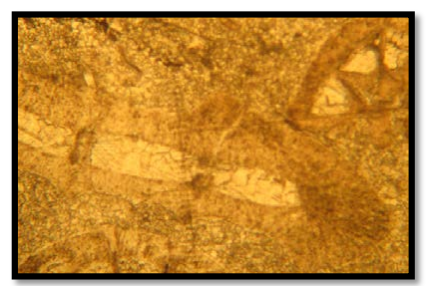

Figure 4: Meridian section of Ranikothalia sindensis

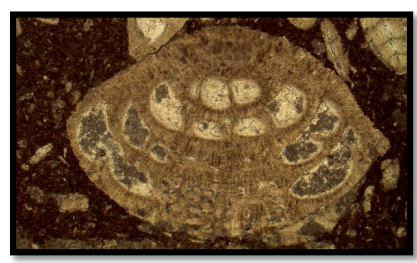

Figure 6: Rotalia trochidiformis

\section{И:}

The study area is the part of Kashmir Basin. The present study is based on the micropaleontology of Margala Hill Limestone and Chorgali Formation. By the detail petrographic studies following foraminifra were identified which includes Nummulites atacicus (LEYMERIE), Nummulites mamillatus (FICHTEL and MOLL), Assilina sub spinose (DAVIES and PINFOLD), Assilina spinosa (DAVIES and PINFOLD,), Assilina laminose (GILL) Assilina exponens (SOWERBY), Textularia sp., (DEFRANCE), Alveolina Vredenburgi(DAVIES), Miliolid sp., Alveolina rotundata bhadrarensis, (Sameeni) Ranikothalia sendensis (DAVIES, 1932) Discocyclina peruviana (CUSHMAN), Rotalia trochidiformis (LAMARCK), Alveoloina pasticillata (SCHWAGER), Alveolina elliptica (SOWERBY) Alveolina gloubosa, (LEYMERIE) Quinqueloculina (d' ORBIGNY) Miliolid sp., (d' ORBIGNY) Alveolina ovulum (SOWERBY) Nodosaria sp (LEMARCK) Lockhartia conditi (NUTTALL), Lockhartia tipper (DAVIES), Dictyocnous indica, Planktons as well as Gastrpods, Dasycladacean algae. and shells of mollusks hasbeen observed in outcrop. The carbonates of Margala Hill Limestone and Chorgali Formation shows that these were deposits in shallow marine environment and mark the transgression and regression of Neotethys Ocean. The nodular Margala Hill Limestone deposits at shallow shelf in early Eocene time. Foetid fossiliferous limestone and presence of dark shales shows accumulation in slightly high energy water has a basin configuration across the Paleocene-Eocene boundary. After the deposition of Patala Formation, during Early Eocene, environment change from open marine to shallow marine due to uplifting. In Eocene time mainly, deposition occurs on low energy ramp type of setting, in moderately arid climate and it marked by low diversity of benthonic forams. At the end of early Eocene carbonate deposition was stopped due to increase of orogenic uplift. Major unconformity was formed on the top of early to middle Eocene carbonate and clastic sediments of Kuldana Formation. Kuldana Formation shows trasitional environment of deposition and indicates the closing of Neothethy Ocean The presence of benthic foraminifera indicated that Margalla Hill Limestone and Chorgali Formation were deposited in the tidal flat environments (i.e., ranging from supratidal to subtidal conditions), whereas Early Eocene age is assigned on the basis of benthic foraminifera observed.

Plate 3

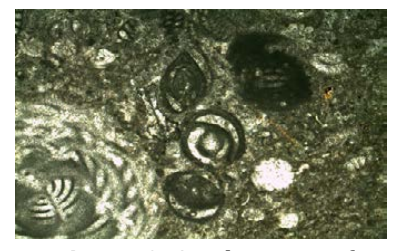

Figure 1: Axial section of Quinqueloculina

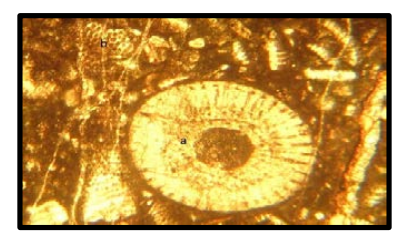

Figure 3: Cross section of green algae.

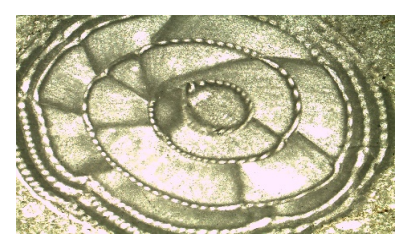

Figure 5: Axial section of Alveolina pasticillata

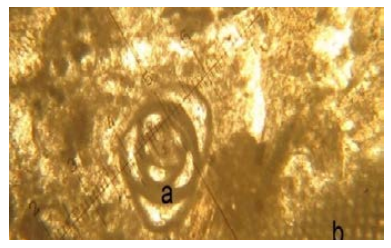

Figure 2: Axial section of Milliolids sp.,

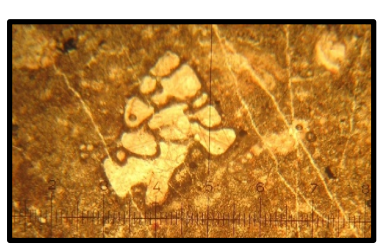

Figure 4: Axial section of Skeasaria ornata

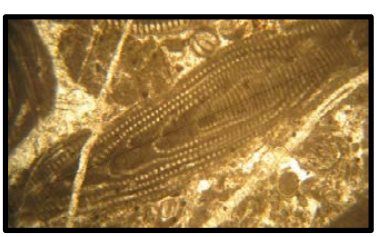

Figure 6: Axial section of Alveolina elliptica

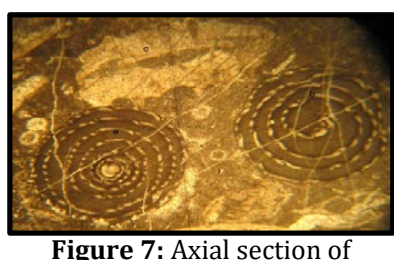

Figure 7: Axial section

Alveolina ovulum

\section{Remarks}

Test is planisprial, usually smooth and is calcareous in nature. Length of test ranges from 5.5-10 $\mathrm{mm}$ and width from 3.5-6.5 mm. Number of whorls vary from 3-5. Protoconch is visible and rounded in shape, septa are present which are slightly curve to straight, thin and vary in number. The end of test is slightly clubbed (Plate1; figure 1).

\section{Nummulities mammillatus (FICHTEL and MOLL, 1798) [14]}

\section{Remarks}

Test is rounded in the center and having sharp border and calcareous in nature. Length of test ranges from $9.3 \mathrm{~mm}$ and width $7.3 \mathrm{~mm}$. Number of whorls vary from 3-5. Protoconch is visible and rounded in shape, septa present which is slightly curve to straight and vary in number.Marginal cord is present and having distinct and prominent polar pustule. (Plate1; figure 2).

\section{Assilina spinose (DAVIES and PINFOLD, 1937) [15]}

\section{Remarks}

Test is biconvex, planisprial, involute and thick walled. Radiating marginal cord is present and periphery is sub rounded to elongate. Spines are originating from sides of test which vary in number. Protoconch is rounded and megalospheric. Initially the size of chamber is gradually increasing and then last or final chambers increasing rapidly. Suture is straight and raised.

Length of test ranges from 10-18 $\mathrm{mm}$ and width 3-4 $\mathrm{mm}$ (Plate 1; figure 3).

Assilina laminose (GILL, 1953) [16]

Remarks

Test is usually smooth along with radiating marginal cord at outer chamber and the walls showing lamellar structure. Walled are thick and some lamination are present on test surface as ornamentation. Periphry is elongated. Length of specie is18-24 $\mathrm{mm}$ and width 4-5 $\mathrm{mm}$ (Plate 1; figure 4). 


\section{Assilina Exponens (SOWERBY, 1840) [17]}

\section{Remarks}

This species having elongated test. Chambers are overlapped and thick marginal cord is also present. Chamber is of conical shape; the length of species is $22 \mathrm{~mm}$ and width is $3 \mathrm{~mm}$. (Plate 1; figure 5).

\section{Textularia sp. (DEFRANCE, 1824)}

\section{Remarks}

Test is biserially coiled. The number of chambers ranges from 2-3. Chamber is varying in shape from elongated to inflate. Composition of tes is arenaceous. Aperture is present in inner margin of last chamber. The average size of this specie is $2.5 \mathrm{~mm}$ in length and width $2 \mathrm{~mm}$. The size of species increases towards aperture size. Suture is depressed (Plate 1; figure $6)$.

\section{Alveolina Vredenburgi (DAVIES, 1937) [15]}

\section{Remarks}

This species has oval to spherical shape and the test is spirally coiled about an axis. Chambers are divided in chamberlets by tangential septa. Whorls are well developed and spacing between them is uniform. Whorls are 8 in number. Average length is $15 \mathrm{~mm}$ and width is $9 \mathrm{~mm}$ (Plate 2; figure 1).

\section{Nodosaria sp. (LEMARCK, 1812)}

\section{Remarks}

Test is uniserially coiled. Chamber is divided by mean of suture which is deeply constricted. The number of chamber ranges from 5-15. The average length is $6 \mathrm{~mm}$ and width is $0.5 \mathrm{~mm}$ (Plate 2; figure 2).

\section{Lockhartia tipperi (DAVIES, 1932)}

\section{Remarks}

This species has low trochospirally coiled shell and periphery is rounded. Pillars which are regular also appear in axial section. Pustules are thick on umbilicale side (Plate 2; figure 3).

\section{Ranikothalia sendensis (DAVIES, 1932)}

\section{Remarks}

This species having fan shaped marginal cord and septal filaments, falttened test.The length of species is $22 \mathrm{~mm}$ and width is $3 \mathrm{~mm}$ (Plate 2 figure 4).

\section{Discocyclina peruviana (CUSHMAN, 1923) [18]}

\section{Remarks}

This species has biconvex shells with numerous pillars. Central part of test is broad while sides are stretched (Plate 2; figure 5).

\section{Rotalia trochidiformis (LAMARCK, 1804) [19]}

\section{Remarks}

Test is free, trochospiral and lenticular to plano-convex septa are primarily double. Wall is coarsely perforated and calcareous (Plate 2; figure $6)$.

Quinqueloculina sp., (d' ORBIGNY, 1826) [20]

\section{Remarks}

Chambers develop in different changing pattern. It has 2-6 chambers which are elongated. Walls are thick, visible, calcareous and imperforated. Each coil is developing by arrangement of two chambers. Usually surface is smooth (Plate 3; figure 1).

\section{Miliolid sp. (d' ORBIGNY, 1826) [20]}

\section{Remarks}

Early arrangement of chambers resembles the chamber arrangement in Quinqueoculina, later arrangement of chamber is take place in a single plane on the both side of test. The entire chambers are visible. Each whorl is formed by two chambers (Plate 3; figure 3).

\section{Algae}

The green algae (Dascyladcean) and the red algae were also observed in thin sections. Codiacean algae sorites sp., found in different thin sections. The sorites species like a shoes string with average length 10-18 mm.Cymbalopora sp., has disc like shape. Red algae is like criss cross network of sieves (Plate 3; figure 3).

\section{Sakesaria ornata (SMOUT, 1954) [21]}

\section{Remarks}

This species having more conical shape. The dorsal ornament is highly distinctive. It consists of finely punctuate chambers and limbate sutures. (Plate 3; figure 4).

\section{Alveolina pasticillata (SCHWAGER, 1883) [22]}

\section{Remarks}

The Test is cylindsical, with rounded ends wall porcellaneous, imperforate, whrols 6-9 in numbers, chemberlets numerous, meglosphere is rounded. (Plate 3; figure 5).

\section{Alveolina elliptica (SOWERBY, 1925)}

\section{Remarks}

Test is cylindrical, with rounded ends. Walls porcellaneous, imperforated, whorls 6-8 in number, chamberlets in a single being higher then broader, megalosphere is small. (Plate 3; figure 6).

\section{Alveolina ovulum (SOWERBY, 1883)}

\section{Remarks}

Test is ovate to elongate cylinderical, with rounded to subrounded ends. Walls porcellaneous, imperforated, whorls 5-7 in number, megalosphere is oval. (Plate 3; figure 7).

\section{Miliolid sp. (d' ORBIGNY, 1826) [20]}

\section{Remarks}

Early arrangement of chambers resembles the chamber arrangement in Quinqueoculina, later arrangement of chamber is take place in a single plane on the both side of test. The entire chambers are visible. Each whorl is formed by two chambers (Plate 3; figure 3).

\section{Algae}

The green algae (Dascyladcean) and the red algae were also observed in thin sections. Codiacean algae sorites sp., found in different thin sections. The sorites species like a shoes string with average length 10-18 mm.Cymbalopora sp., has disc like shape. Red algae is like criss cross network of sieves (Plate 3; figure 3).

\section{Sakesaria ornata (SMOUT, 1954) [21]}

\section{Remarks}

This species having more conical shape. The dorsal ornament is highly distinctive. It consists of finely punctuate chambers and limbate sutures. (Plate 3; figure 4).

\section{Alveolina pasticillata (SCHWAGER, 1883) [22]}

\section{Remarks}

The Test is cylindsical, with rounded ends wall porcellaneous, imperforate, whrols 6-9 in numbers, chemberlets numerous, meglosphere is rounded. (Plate 3; figure 5). 


\section{Alveolina elliptica (SOWERBY, 1925)}

\section{Remarks}

Test is cylindrical, with rounded ends. Walls porcellaneous, imperforated whorls 6-8 in number, chamberlets in a single being higher then broader megalosphere is small. (Plate 3; figure 6).

\section{Alveolina ovulum (SOWERBY, 1883)}

\section{Remarks}

Test is ovate to elongate cylinderical, with rounded to subrounded ends Walls porcellaneous, imperforated, whorls 5-7 in number, megalosphere is oval. (Plate 3; figure 7).

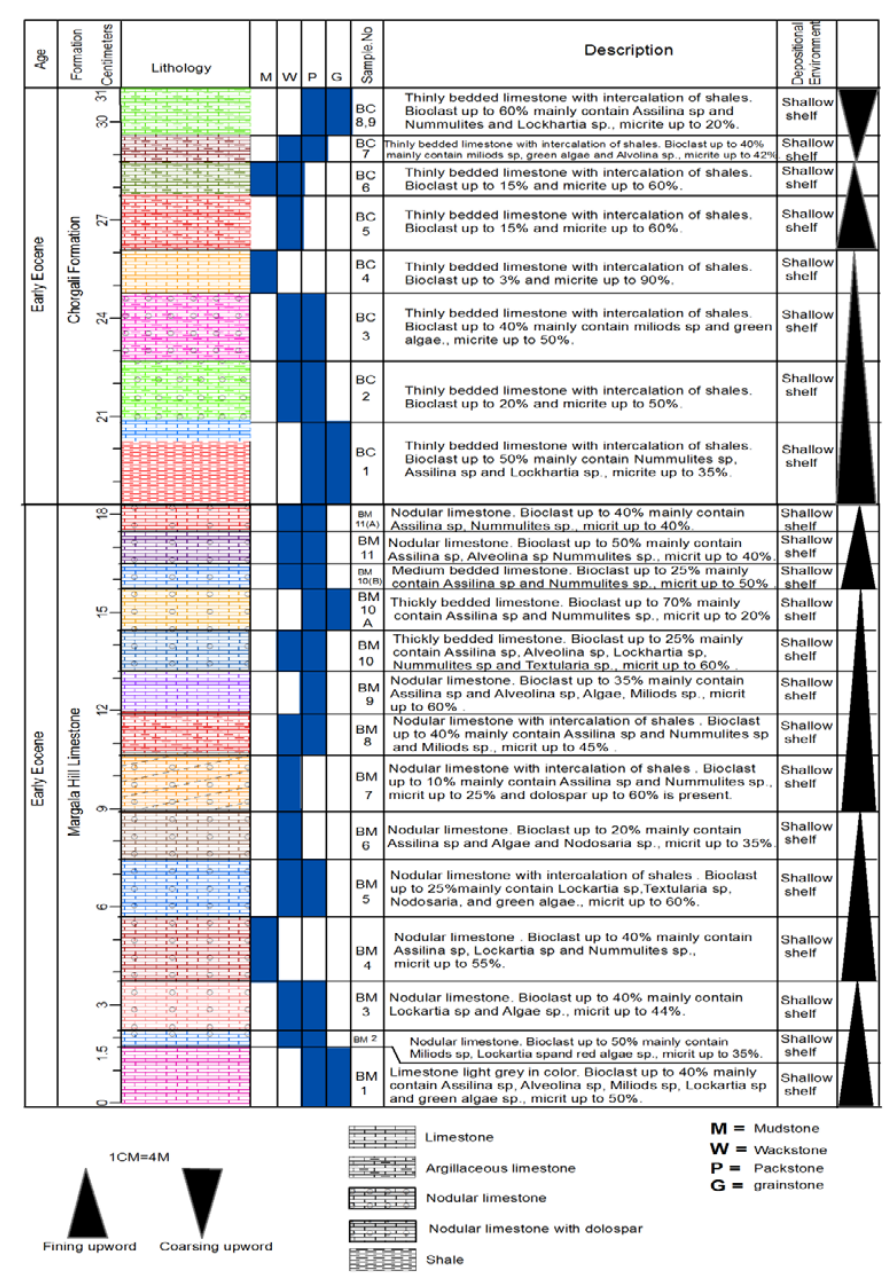

Figure 3: The sequence stratigraphy of the area. The Chorgali to onward formations are concern of research in the area.

\section{REFFERENCE}

[1] Lydekker, R. 1883. The Geology of Kashmir and Chamba territories and the British District of Khagan. Memoirs of the Geological Survey of India, 22, $1-344$.

[2] Wadia, D.N. 1930. Hazara Kashmir Syntaxis. Records, Geological Survey of India, 129, 1-138.

[3] Calkins, J.A., Offield, T.W., Abdullah, S.K.M., and Tayyab, A.S. 1975. Geology of the southern Himalayan in Hazara, Pakistan and adjacent areas. United States Geological Survey Professional Paper, 716-C: 29 p Carozzi, A.V., 1993:
[4] Ghazanfar, M., and Chaudhry, M.N. 1986. Reporting MCT in northwest Himalaya, Pakistan. Geological Bulletin of Punjab University, 21, 10-18.

[5] Burbank, D.W., Raynolds, R.G.H., and Johnson, G. D. 1986. Late Cenozoic tectonics and sedimentation in the north-west Himalayan foredeep II. Eastern limb of the Northwest Syntaxis and regional synthesis. In Allen, P.A., \& Homewood, P., (eds), Foreland Basin. Special publication of the international Association of Sedimentologist.Special publication, 8, 293-306.

[6] Baig, M.S., and Lawrence, R.D. 1987. Precambrian to early Paleozoic Orogenesis in the Himalayas. Kashmir Journal of Geology, 5, 1-22.

[7] Wells, N. A., and Ginngerich, P. D. 1987. Paleoenvironmental interpretation of Paleogene strata near Kotli, Azad Kashmir, Northeastern Pakistan: Kashmir. Journal of Geology, 5, 23-42.

[8] Bossart, P., Dietrich, D., Greco, A., Ottiger, R., and Ramsay, J. G. 1988. The tectonic structure the Hazara Kashmir Syntaxis, southern Himalaya, Pakistan. Tectonics, 7, 273-297.

[9] Greco, A. 1991. Stratigraphy, metamorphism and tectonics of the Hazara Kashmir Syntaxis area. Kashmir Journal of Geology, 8 (9), 39-66.

[10] Tapponnier, P., King, G., Bollinger, L., and Grasso, J. 2006. Surface faulting during the October 8th, 2005, Muzaffarabad earthquake and Coulomb stress increase on the Jhelum fault. Seismological Research Letter, 77-234.

[11] Baig, M.S. 2006. Active faulting and earthquake deformation in Hazara Kashmir Syntaxis, Azad Kashmir, Northwest Himalaya, Pakistan. In: Kausar, AB., Karim, T., Khan, T., editors Extended Abstracts, International Conference on 8 October 2005 earthquake in Pakistan. Its implications and hazard mitigation. Geological Survey of Pakistan, 21-22.

[12] Baig, M. S., and Munir, M. H. 2006. Paleogene biostratigraphy of Tattapani, Kotli Azad Kashmir, Northwest Sub-Himalayas, Pakistan: Journal of Himalayan Earth Sciences, 39, 39-48.

[13] Baig, M.S., and Munir, M. 2007. Foraminiferal Biostratigraphy of Yadgar area, Muzaffarabad Azad Kashmir, Pakistan. Journal of Himalayan Earth Sciences, 40, 33-43.

[14] Fichtel, L.V., Moll, J.P.C., and Von. 1798. Tesacea microscopic, aliaqueminuta ex generibus Argonautaet Naulilus, ad naturampicta et descripta (Microscopische and andere Klein Schalthierreaus den Geschlechtern Arogonnaute and Schiffer), 7, 123.

[15] Davies, L.M., and Pinfold, E.S. 1937. The Eocene beds of the Punjab Salt Range. Geological Survey of India, Memoir, Palaeontologia Indica, New Series, 24 (1),79.

[16] Gill, W.D. 1953. The genus Assilina in the Laki Series (Lower Eocene) of the Kohat-Potwar Basin, northwest Pakistan. Contributions Cushman laboratory foraminiferal research, 4 (2), 76-84.

[17] Sowerby, J., and De, C. 1840. Systematic description of organic remains of cutch, Transactions of the Geological Society, 2, 327-329.

[18] Lamarck, J. B. 1801. Systeme des animaux sans vertebras, Linda Hall Library, LHL Digital Collections, 432.

[19] Cushman, J.A. 1932. Textularia and realted forms from Cretaceous. Contributions Cushman laboratory foraminiferal research, 8, 86-97.

[20] Orbigny, A. D. 1826. Tableau methodique de lo classe des cephalopoda. Annales des sciences naturelles, 7, 1-275.

[21] Smout, A. H. 1954. Lower Tertiart foraminifera of the Qatar Peninsula. London: British Museum (Natural History), 69.

[22] Schwager, C. 1883. Die Foraminifera aus den Eocene ablagerungen der Libsychen wust und Aegypten. paleontographical, 78-153.

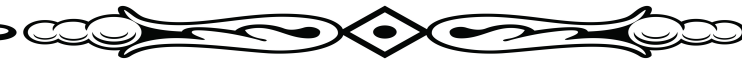

